\title{
The Value of Serving as a Peer Reviewer: an Editorial
}

Cheryl J. Hill

Nova Southeastern University, hill@nova.edu

Follow this and additional works at: https://nsuworks.nova.edu/ijahsp

Part of the Medicine and Health Sciences Commons

\section{Recommended Citation}

Hill CJ. The Value of Serving as a Peer Reviewer: an Editorial. The Internet Journal of Allied Health Sciences and Practice. 2018 Jan 01;16(3), Article 8.

This Editorial is brought to you for free and open access by the College of Health Care Sciences at NSUWorks. It has been accepted for inclusion in Internet Journal of Allied Health Sciences and Practice by an authorized editor of NSUWorks. For more information, please contact nsuworks@nova.edu. 


\section{The Value of Serving as a Peer Reviewer: an Editorial}

\section{Author Bio(s)}

Cheryl J. Hill, PT, DPT, PhD, is a full professor in the Patel College of Health Care Sciences at Nova Southeastern University in Ft. Lauderdale, FL. She has been involved as a reviewer and copy editor with the Internet Journal of Allied Health Sciences and Practice since its inception in 2001, and in 2016, she was promoted to the position of Editor-in-Chief for the Journal. 


\section{TIUASP \\ The Internet Joưnal of Allied Health Sciences and Practice}

Dedicated to allied health professional practice and education

Vol. 16 No. 3 ISSN 1540-580X

The Value of Serving as a Peer Reviewer: Editorial

Cheryl J. Hill

Nova Southeastern University

United States

One of the things we all share is that each of us only has 24 hours in a day. As we take on more and more responsibilities in our work life and our home life, and as life itself becomes more and more complicated, time becomes a precious commodity. As a result, we all need to step back now and then and reflect on what we are doing with our precious time. It is from this position that I began to wonder about the value of serving as a peer reviewer for scholarly journals.

When I began reading various sources about peer review, I found articles both in support of peer review as well as articles that pointed out potential weaknesses of peer review. Those who are critical of peer review speak of issues such as the time it takes to do peer review (slows down the publication time and may hamper the progress of a researcher if he/she has planned a series of experiments); the enormous cost in time from start to finish: those who evaluate papers are not infallible and time demands may militate perfection in the review process; the fact that there is potential bias on the part of a reviewer if the research is competing with his/her own research; for international journals, there is the risk that decisions may be influenced by the country of the reviewer; and last, peer reviewers can steal ideas and present them as their own. Naysayers also claim there is no proof that peer review actually improves the quality of articles in a journal. ${ }^{1,2}$ And yet, peer review has been compared to democracy: it is a system full of problems, but still the best we have. ${ }^{2}$

From a personal perspective, I saw the value(s) of serving as a peer reviewer. For 14 years, before becoming the Editor-in-Chief of this Journal, I served as a reviewer and the sole copy editor. Each manuscript I reviewed added something to my own knowledge base. Because peer reviewing requires critical thinking, it also provided me with new insights into my own work. Even the manuscripts that were not well-written had something to offer me in terms of what not to do or what to avoid when writing up the findings of a study. ${ }^{3}$ I found that reviewing the work of other scholars gave me ideas for enhancing my own research agenda.

"It is a reasonable assumption that the work that actually gets published represents the top $20-30 \%$ of what is submitted for consideration. ${ }^{3(\text { para5) }}$ This means that peer reviewers get early access to (presumably) high quality research before it is published to a journal's readership. Indeed, the fact authors know their work will be scrutinized raises the standard of a [submission] before it is even sent to a journal. ${ }^{4}$

(c) The Internet Journal of Allied Health Sciences and Practice, 2018 
The process of peer reviewing an article provides the reviewer with the opportunity to reflect on someone else's work and to provide thoughtful feedback to the author. Doing so helps other scholars to succeed. In addition, in the US, providing peer review service to a scholarly journal is considered service to the profession that can be added to one's curriculum vitae.

Peer review and those who provide it may contribute to identifying scientific misconduct in a manuscript. A peer reviewer may note that they have read the manuscript in another journal, or that a specific reference has nothing to do with the topic of the paper. Editorial boards are always on the alert for potential abuse of a journal, and though authors are presumed to be submitting legitimate work, more often than not, a peer reviewer will be the first to discover otherwise.

Peer review is a two-way street. It benefits both the reviewer and the author. A number of benefits to the reviewers have already been mentioned. The benefit to authors is that they have time to reflect on how their research is viewed by experts in the field. It is a time when improvements can be made to a manuscript via the communication between the reviewer and the author. In addition, authors and reviewers share the ethical responsibility of making sure that the bases upon which claims are made are scientifically sound. In medical research, this may impact people's lives; therefore, such research should be subject to careful scrutiny.

Journal editors are always seeking skilled reviewers to guide their journal's decision-making efforts. ${ }^{3}$ The goal of every editor is to find skilled, knowledgeable reviewers who will take the time to do a credible job of providing a meaningful review of a manuscript. More often than not, these reviewers are unpaid for their services, and some journals do not even publish the names of the reviewers who contributed to a given edition. We do publish the names of reviewers, but not which article they reviewed, in order to achieve a balance between acknowledgment and anonymity. This is a scant reward for the efforts of these unsung heroes, so to each of them, I say, "Thank you from the bottom of my heart. We could not do this without you."

Cheryl J. Hill, PT, DPT, PhD

Editor-in-Chief

\section{References}

1. Kelly J, Sadeghieh T, Adeli K. Peer Review in Scientific Publications: Benefits, Critiques, \& A Survival Guide. EJIFCC. 2014 Oct;25(3):227-43. [PMID: 27683470]

2. Smith R. Peer review: a flawed process at the heart of science and journals. J R Soc Med. 2006 Apr;99(4):178-82. [PMID: 16574968]

3. Rosenbaum P. On the value of being a journal reviewer. Dev Med Child Neurol. 2005 Mar;47:147. [PMID: 15739716] DOI: $10.1017 / S 0012162205000265$

4. Gannon F. The essential role of peer review. EMBO Rep. 2001 Sep;2(9):743. [PMID: 11559578] doi:10.1093/embo-reports/kve188. 